Ann. Biol. anim. Bioch. Biophys., 1979, 19 (4 B), 1351-1361.

\title{
Ontogeny of responsiveness to gonadotrophins and prostaglandin $E$ in the neonatal rat ovary
}

\author{
par S. A. LAMPRECHT, Bruria FUNKENSTEIN, A. NIMROD \\ Depariment of Hormone Research \\ The Weizmann Institute of Science, Rehovot, Israel.
}

Summary. The role of LH, FSH, PGE ${ }_{2}$, cyclic AMP and testosterone in the development of ovarian hormonal responsiveness and steroidogenic capability was studied by shortterm incubations and organ culture of neonatal rat ovaries.

Perinatal ovaries responded in vitro to $\mathrm{PGE}_{2}$ but not to $\mathrm{LH}$ with a marked increase in cyclic AMP production. The ovaries responded very feebly to $\mathrm{LH}$ challenge throughout the first neonatal week. During the second week post partum the ovarian response to both agonists increased markedly. A similar temporal pattern in the response to $\mathrm{LH}, \mathrm{FSH}, \mathrm{PGE}_{2}$ or exogenous cyclic AMP by the infantile rat ovary was noted when hormone stimulation of cestradiol-17 $\beta$ release was assessed during a 4-h incubation period.

Ovaries of 4-day old rats cultured for 2-12 days in medium without hormonal supplementation produced small and decreasing amounts of steroids. The addition of $\mathrm{LH}$ did not alter progesterone production during the first 4 days of culture but significantly stimulated it during Days 4-8 of culture. FSH and testosterone $(1 \mu \mathrm{g} / \mathrm{ml})$ had no effect on their own, but when FSH or testosterone were added together with LH, progesterone production during Days 4-10 of culture was greatly enhanced. The acquisition of responsiveness to LH did not depend on previous exposure to the hormone, since a full response in progesterone production to $\mathrm{LH}$ was obtained in the ovaries after 4-8 days of culture without $\mathrm{LH}$ addition.

Production of œstradiol-17 $\beta$ was slightly enhanced by LH during Days 4-10 of culfure. FSH had no effect on its own, but augmented the effect of $\mathrm{LH}$. The addition of testosterone alone significantly stimulated astradiol production even during the first 2 days. This effect of exogenous testosterone was greatly enhanced by FSH.

It is concluded that the ability of the neonatal ovary to respond to LH by the eighth day post partum is acquired by an autonomous developmental process and is not dependent upon previous exposure to gonadotrophins and steroid hormones. However, once sensitivity to the gonadotrophin is attained, steroidogenesis is controlled by an interplay of gonadotrophins and steroid hormones. In contrast to LH, the ovaries are responsive to $\mathrm{PGE}_{2}$ at birth.

\section{Introduction.}

The indispensability of gonadotrophic hormones in controlling and supporfing morphological and functional processes in the mature ovary is well established, but the precise time of the onset of gonadotrophin dependence by the ovary is still a matfer of controversy. It has been suggested that follicular development is independent of pituitary control during the early stages of postnatal development (Price and Ortiz, 
1944 ; Paesi, 1949 ; Hertz, 1963). This view derived mainly from studies in which intact or hypophysectomized animals were injected with exogenous gonadotrophins.

Following in vivo administration of PMSG to female neonatal rats, Goldenberg and co-workers (1973) examined the age-related changes in ovarian weight and follicular morphology and growth, and concluded that initiation of ovarian response to gonadotrophins occurs between Days six and eight after birth. Peters et al. (1973) suggested that gonadotrophins did not stimulate the initiation of development of small resting follicles. However, morphological changes have been observed in murine ovaries deprived of endogenous gonadotrophin support from birth by administration of specific antisera (Eshkol et al., 1970 ; Schuchner and Monastirsky, 1973 ; Schwartz, 1974 ; Schwartz ef al., 1974 ; Anderson et al., 1976 ; Purandare et al., 1976).

The crucial question whether gonadotrophins are essential for initiation of follicular growth, or play a later role in the maintenance of follicular development once the first waves of follicular growth have emerged spontaneously in the neonatal ovary, is still unresolved. It seems, however, that competence of the ovary to respond to gonadotrophins in terms of cyclic AMP formation and œstrogen synthesis is acquired only after the first neonatal week (Falck, 1953 ; Lamprecht et al., 1973 ; HunzickerDunn and Birnbaumer, 1976 ; Kolena, 1976a, b ; Lamprecht ef al., 1976), at a time when autoradiographic studies of 125 -hCG binding (Presl et al., 1972) have evidenced a specific uptake of radioactivity by the ovary. It is also during the second week post partum that the rat ovary markedly converts progesterone (Quattropani and Weisz, 1973) or dehydroepiandrosterone (Smeaton et al., 1975) to œstrogens.

In spite of significant levels of FSH and LH in the peripheral blood of rats throughout the first two neonatal weeks (Dohler and Wuttke, 1975 ; Meijs-Roelofs ef al., $1973,1975)$ plasma progesterone levels are exceedingly low during the first ten days post partum. By contrast, estrogen levels are elevated during the first two neonatal days but there is substantial evidence supporting a maternal source of the steroid (Friend, 1977). They soon decline and remain low during the first week (Meijs-Roelofs et al., 1973 ; Dohler and Wuttke, 1975).

Conflicting results have been obtained from studies of perinatal ovaries in organ culture. While folliculogenesis in cultured rat neonatal ovaries seems to be able to be initiated in the absence of exogenous gonadotrophins (Levina ef al., 1975), the process of follicular development was severely impeded in mouse ovaries explanted on the second neonatal day and cultured in hormone-free medium (Baker and Neal, 1973). The addition of either LH or FSH partially restored ovarian growth.

In the present study, short-term incubations and organ culture of rat ovaries were used to investigate the ontogeny of the ovarian competence to secrete steroids in response to hormonal challenge and to identify some of the regulatory agents involved in this process.

\section{Materials and methods.}

Short-term incubation studies.

1. Assay of $\left[{ }^{3} \mathrm{H}\right]$ cyclic AMP formation in ovarian tissue. - Adenylate cyclase activity of ovaries from infantile rats was determined by the conversion of $\left[{ }^{3} \mathrm{H}\right]$ adenine to $\left[{ }^{3} \mathrm{H}\right]$ cyclic AMP in vitro, as described in detail by Lamprecht et al. (1973). 
2. Production of œstradiol-17 $\beta$. - Neonatal ovaries were incubated for $4 \mathrm{~h}$ and the amount of œestradiol- $17 \beta$ secreted into the medium was determined by radioimmunoassay, as described by Lamprecht ef al. (1976).

Organ culture.

Ovaries from 4-day old rats were maintained in organ culture 6 ovaries $11 \mathrm{ml}$ dish under 60 p. $100 \mathrm{O}_{2}$ and 40 p. 100 air) for 2 to 12 days in Eagle's Minimum Essential Medium with Earle's salts supplemented with 10 p. 100 fetal calf serum, insulin $(5 \mu \mathrm{g} / \mathrm{ml})$ and gentamycin $(1 \mu \mathrm{g} / \mathrm{ml})$. In addition, it contained hormones in various combinations. The culture medium was replaced every $48 \mathrm{~h}$, and the steroid hormone contents were determined by radioimmunoassay. The culture method and assay procedure are described in detail elsewhere (Funkenstein ef al., in press).

\section{Results.}

Short-term incubation studies of infantile rat ovaries.

1. Temporal dissociation in the response to $L H$ and $P G E_{2}$ in terms of cyclic AMP production. - The effect of $\mathrm{LH}(10 \mu \mathrm{g} / \mathrm{ml})$ and of $\mathrm{PGE}_{2}(10 \mu \mathrm{g} / \mathrm{ml})$ on ovarian $\left[{ }^{3} \mathrm{H}\right]$ cyclic AMP formation from the perinatal period until puberty is shown in table 1. Ovaries from rat fœtuses collected 1 day before term responded in vitro to $P_{G E}$ but not to $L H$ with a marked increase in cyclic AMP formation (650 p. 100, increase). The ovaries responded feebly to $\mathrm{LH}$ (21-93 p. 100 increase) throughout the first neonatal week. The response to $P G E_{2}$ declined somewhat during this week, though it remained well

\section{TABLE 1}

Ovarian cyclic AMP production in response to $\mathrm{LH}$ and $\mathrm{PGE}_{2}$ during the perinatal period and prepubertal development of the rat

\begin{tabular}{ccc}
\hline & \multicolumn{2}{c}{$\begin{array}{c}{\left[{ }^{3} \mathrm{H}\right] \text { Cyclic AMP production }} \\
\text { (p. 100 over control) }\end{array}$} \\
\cline { 2 - 3 } & LHe (days after birth) & $\mathrm{PGE}_{2}$ \\
\hline 1 & $53 \pm 14$ & $650 \pm 60$ \\
2 & $31 \pm 2$ & $450 \pm 42$ \\
5 & $21 \pm 22$ & $195 \pm 11$ \\
6 & $55 \pm 7$ & $145 \pm 10$ \\
7 & $93 \pm 10$ & $236 \pm 16$ \\
8 & $106 \pm 5$ & $178 \pm 6$ \\
9 & $93 \pm 15$ & $423 \pm 82$ \\
10 & $295 \pm 17$ & $568 \pm 70$ \\
12 & $729 \pm 67$ & $196 \pm 170$ \\
18 & $683 \pm 96$ & $722 \pm 148$ \\
30 & $608 \pm 61$ & $613 \pm 48$ \\
\hline
\end{tabular}

The conversion of $\left[{ }^{3} \mathrm{H}\right]$ adenine-labeled endogenous ATP into $\left[{ }^{3} \mathrm{H}\right]$ cyclic AMP by whole ovaries during a 30 min incubation was measured. Shown are mean values \pm SEM for six determinations. 
above that evoked by LH. During the second neonatal week, the ovarian response to both agents increased markedly and reached a plateau, which was maintained until puberty.

2. Hormonal stimulation of $17 \beta$-œstradiol release as a function of age. - The basal rate of cstradiol accumulation in the incubation media of neonatal ovaries was significantly higher on day 9 than on day $8(p<0.01)$ or $7(p<0.05)$ of age. Addition to the incubation medium of LH $(10 \mu \mathrm{g} / \mathrm{ml}), \mathrm{FSH}(50 \mu \mathrm{g} / \mathrm{ml})$ or $\mathrm{PGE}_{2}(10 \mu \mathrm{g} / \mathrm{ml})$ had no measurable effect on cestradiol release into the medium by the ovary of 6-day old rats. All three substances caused a marked and highly significant $(p<0.001)$ augmentation of cestradiol release by ovaries from 8-and 9-day old animals (fig. 1). Moreover, by the age of 9 days, 8-Br-cyclic AMP $(1 \mathrm{mM})$ also enhanced accumulation of œstradiol by the rat ovaries.

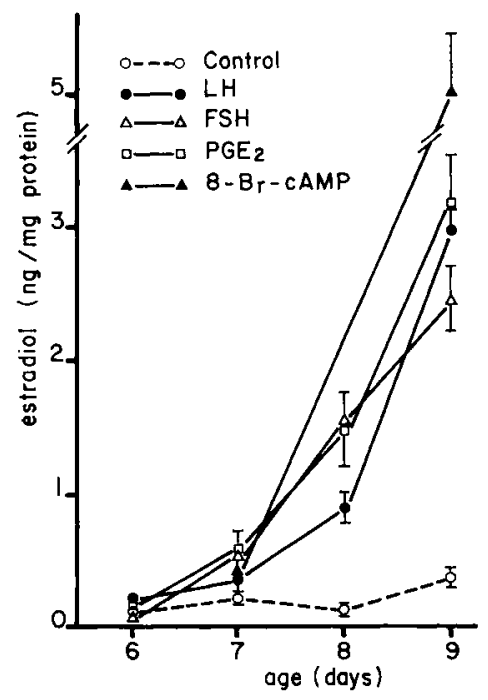

FIG. 1. - Effect of age on cestradiol release by rat ovaries in response to hormones or cyclic AMP in vitro. Shown is cestradiol accumulation per mg ovarian protein (mean \pm S. E. M. ; $n=6$ ) in the medium during a $4 \mathrm{~h}$ incubation with LH $(10 \mu \mathrm{g} / \mathrm{ml})$, FSH $(50 \mu \mathrm{g} / \mathrm{ml})$, PGE $(10$ $\mu \mathrm{g} / \mathrm{ml}$ ), 8-bromo adenosine 3' 5'-cyclic monophosphoric acid (8-Br-cAMP ; $1.0 \mathrm{mM}$ ) or in control medium.

In order to exclude the possibility that the steroidogenic action of FSH was due to $\mathrm{LH}$ contamination, FSH was preincubated, in a number of experiments, with an antiserum directed against the $\beta$ subunit of oLH (Koch et al., 1973). The stimulatory effect of cestrogen formation by FSH on the infantile ovary was not impaired by previous exposure of the hormone to the anti-LH serum and thus represents an intrinsic attribute of the FSH molecule. Ovine prolactin $(10 \mu \mathrm{g} / \mathrm{ml})$ was ineffective in all age groups.

Organ culture studies of neonatal rat ovaries.

1. Ontogeny of hormonal stimulation of progesterone production. - Ovaries of 4-day old rats cultured for 10 days in medium without hormone supplementation accumulated only small amounts of progesterone and the rate of secretion declined over the first 6 days (table 2). When LH $(1 \mu \mathrm{g} / \mathrm{ml}$ ) was added to the culture medium progesterone accumulation was not significantly altered during the first 4 days of culture, 
but was elevated during days $4-8$ of incubation $(p<0.01)$. An even greater and more lasting (4-10 days) elevation of progesterone secretion was caused by the addition of $10 \mu \mathrm{g} / \mathrm{ml} \mathrm{oLH}(\mathrm{p}<0.001)$. Extension of the culture period to 12 days or more resulted in a decline in progesterone secretion. The addition of FSH $(0.5 \mu \mathrm{g} / \mathrm{ml})$ alone to the medium did not result in enhanced production of progesterone (fig. 2), but when added together with ovine LH $(1 \mu \mathrm{g} / \mathrm{ml})$, progesterone levels were higher than those obtained by LH alone during days 4-10 of culture $(p<0.01)$. The effect of testosterone $(1 \mu \mathrm{g} / \mathrm{ml})$ on progesterone production was also tested in this system : the androgen on its own did not affect progesterone accumulation (fig. 2). When added together

\section{TABLE 2}

Effect of $\mathrm{LH}$ on progesterone secretion by cultured ovaries from 4-day old rats.

Ovaries (6 ovaries per $1 \mathrm{ml}$ organ culture dish) were cultured with or without addition of ovine LH and the medium was replaced every $48 \mathrm{~h}$. The values represent the mean $\pm S E M$ for $n>2$ replicate cultures, or mean \pm range for $n=2$ of progesterone accumulation during $48 \mathrm{~h}$ in the culture media.

In brackets, the number of replicate culfures assayed by radioimmunoassay

\begin{tabular}{lccccccc}
\hline & \multicolumn{7}{c}{ Progesterone (pg/dish/2 days) } \\
\cline { 2 - 7 } Days in culture & $0-2$ & $2-4$ & $4-6$ & $6-8$ & $8-10$ & $10-12$ \\
\hline No additions & $81 \pm 13(10)$ & $52 \pm 8(10)$ & $39 \pm 4(10)$ & $36 \pm 4(10)$ & $38 \pm 3(8)$ & $41 \pm 5(2)$ \\
oLH $(1 \mu \mathrm{g} / \mathrm{ml})$ & $51 \pm 12(4)$ & $82 \pm 21(4)$ & $181 \pm 35(4)$ & $142 \pm 42(4)$ & $42 \pm 32(2)$ & $52 \pm 23(2)$ \\
oLH $(10 \mu \mathrm{g} / \mathrm{ml})$ & $108 \pm 12(8)$ & $137 \pm 25(8)$ & $396 \pm 56(8)$ & $378 \pm 67(8)$ & $412 \pm 94(6)$ &
\end{tabular}

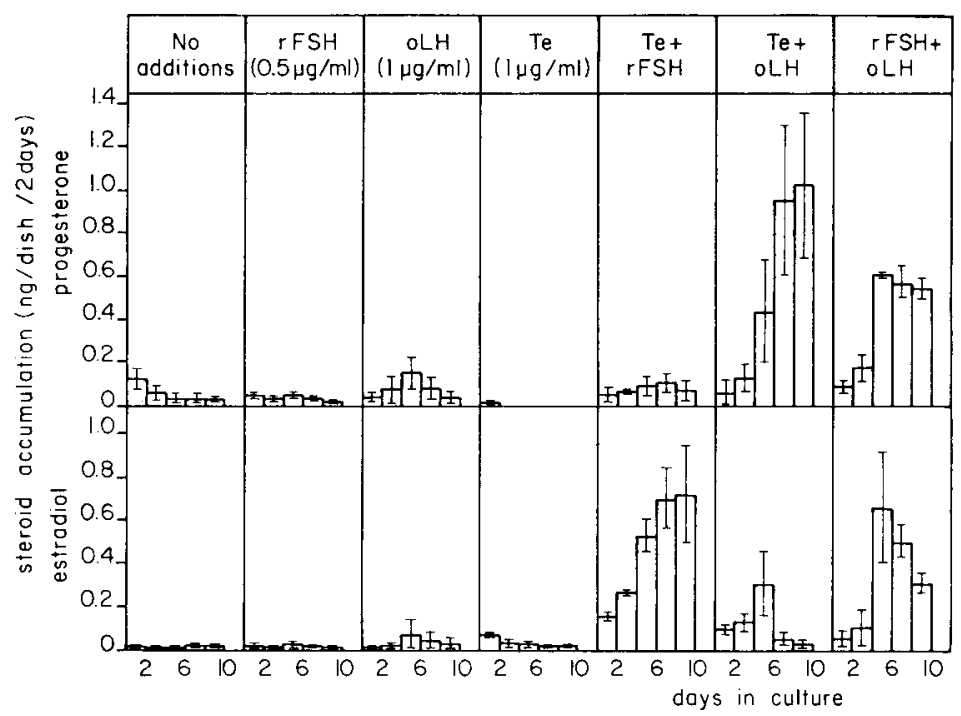

FIG. 2. - Effect of ovine LH (oL.H), rat FSH (rFSH) and festosferone (Te) in vorious combinations on œstradiol and progesterone accumulation in the medium of cultures of ovaries from 4-day old rats. The vertical bars represent the mean \pm range of steroid accumulation during $48 \mathrm{~h}$ in the media of duplicate cultures. 
with $\mathrm{LH}$, testosterone markedly enhanced the effect of gonadotrophic hormones during days $4-10$ of culture $(p<0.01)$.

2. Estradiol production. - Ovaries cultured for 10 days without hormone addition did not accumulate a significant amount of œstradiol in the medium (fig. 2). LH slightly stimulated œestradiol secretion on days $4-10$ of culture $(p<0.05)$, i. e., in parallel with the rise in progesterone secretion whereas FSH $(0.5 \mu \mathrm{g} / \mathrm{ml})$ was without effect. However, a combination of FSH and LH caused a marked increase in œstradiol production during Days 4-10 of culture to levels 5-10 times higher than those obtained with LH alone (485 vs $57 \mathrm{pg} / \mathrm{ml}$, respectively ; $\mathrm{p}<0.01$ ). Addition of testosterone alone to the cultures resulted in elevated cestradiol levels even during the first days of incubation, thus suggesting the existence of basal aromatase activity in ovaries of 4-day old rats. In contrast to the effect of FSH alone, the combination of rat FSH and testosterone greatly enhanced œstradiol production. This effect was already evident during the first two days of culture, and further increased thereafter. A synergistic effect was also observed when testosterone was added with $\mathrm{LH}$, but the increase in cestradiol formation was more limited and shorter in duration.

3. Spontaneous acquisition of responsiveness to $L H$. - Ovaries were put into culture without LH and the hormone was added after 4 or 8 days of incubation. Control cultures received $\mathrm{LH}$ throughout the entire 10-day period. The results, shown in figure 3 , indicate that 4 days of culture even without $\mathrm{LH}$ addition permitted the development of the ovarian responsiveness to subsequent exposure to the hormone. Ovarian responsiveness to LH was also evident after prolonged culture in the absence of LH (8 days), as shown by enhanced progesterone production when $\mathrm{LH}$ was added to the medium during Days 9 and 10 of incubation.

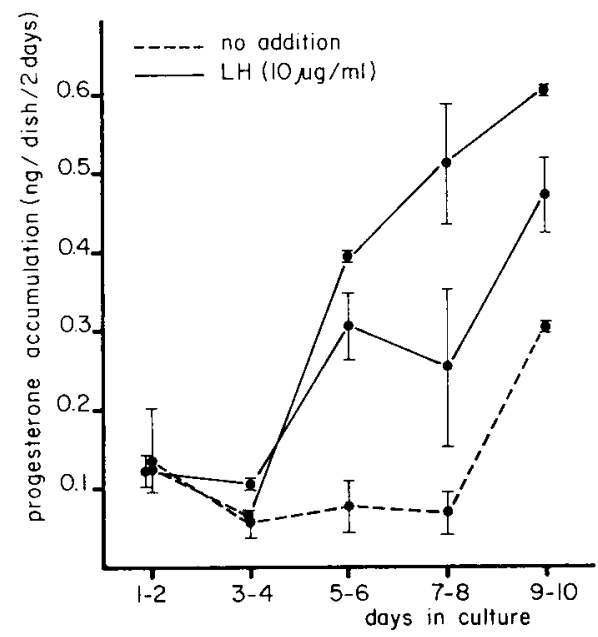

FIG. 3. - Effect of exposure to LH on the development of hormonal responsiveness in culfured ovaries from neonatal (4-day old) rats. Ovaries were first cultured without LH addition (broken line), followed by culture in LH-supplemented media (solid line). Mean \pm range of $48 \mathrm{~h}$ progesterone accumulation in duplicate cultures. 


\section{Discussion.}

The minimal requirements for a cellular response of the ovary to gonadotrophins and PGE are now held to include (i) the presence of specific recognition sites on the cell membrane; (ii) the membrane-bound adenylate cyclase; (iii) effective coupling between these two components ; (iv) cyclic AMP stimulable protein kinase(s); and (v) functional steroidogenic pathways. In the ovary of 1 to 6-day old rats these conditions are not yet realized : at this stage of development the ovary fails to respond to $\mathrm{LH}$ and FSH stimulation with enhanced adenylate cyclase activity (Hunzicker-Dunn and Birnbaumer, 1976), increased cyclic AMP formation (table 1, Lamprecht et al., 1973) and œstradiol secretion (fig. 1 ; Lamprecht et al., 1976). It is also at the chronological age of 8 days that ovarian rat explants in culture first respond to LH stimulation with increased progesterone formation (table 2).

The significance of the high levels of circulating gonadotrophins in the infantile female rat is still unclear. While LH and FSH seem to support some facets of ovarian morphogenesis during the perinatal period (see Introduction), acquisition of LH-responsiveness by the infantile rat ovary, in terms of a steroidogenic response, appears to be an inherent part of their developmental program, since it occurred spontaneously in ovaries maintained in culture for four days without hormone supplementation (fig. 3). This observation is supported by the findings of Kraiem et al. (1976, 1979), who reported that the enzymatic system necessary for ovarian cyclic AMP formation and œstradiol biosynthesis in mice develops normally following gonadotrophin deprivation from birth.

The lack of a steroidogenic response to LH observed in rat ovaries during the early posinatal period could have been due to an absence of specific binding sites for the hormone (Presl et al., 1972 ; Siebers ef al., 1977a, b). Alternatively, absence or inactivity of the coupling step between the adenylate cyclase system and the LH-recepfor would also similarly deprive the ovary of hormonal signals. Examples have been reported suggesting a temporal dissociation in the appearance of the regulatory and catalytic subunits of adenylate cyclase in some organs and species (Rosen and Rosen, 1968 ; Schmidt et al., 1970 ; Perkins, 1973).

The possibility may be raised that the lack of the steroidogenic response to LH by the ovary before reaching the age of 8 days of life - or the corresponding chronological age in culture - results from a deficiency of steroidogenic enzymes. A recent interesting observation that exogenous cyclic AMP stimulates progesterone secretion in ovaries freshly explanted from 4-day old rats within $16 \mathrm{~h}$ of culture (Nimrod et al., in press ; Funkenstein et al., in press) indicates that a cyclic AMP responsive steroidogenic apparatus is available even at this early stage of ovarian growth. Moreover, $\mathrm{PGE}_{2}$ was effective in stimulating progesterone production by ovaries from 4-day old rats already during the first $48 \mathrm{~h}$ of culture (Funkenstein and Nimrod, unpublished). These findings seem to contradict the results obtained from short-term incubation studies (Lamprecht et al., 1973, 1976 ; table 1, fig. 1) : Exogenous cyclic AMP was unable to stimulate cestradiol formation in 6-day old rat ovary (fig. 1) and $P_{G} E_{2}$ fails to enhance ovarian œstradiol synthesis in the infantile rat, although it stimulates cyclic AMP formation from birth (table 1). Ovarian protein kinase, which is considered to 
be an integral part of the cyclic AMP steroidogenic apparatus, first responds to cyclic AMP stimulation during the second neonatal week (Lamprecht ef al., 1973 ; De Angelo ef al., 1975). How, then, is it possible to reconcile these findings with the stimulatory action on steroidogenesis by cyclic AMP in neonatal cultured rat ovaries? It should be noted that in the short-term experiments the ovary was exposed to the agonists for brief periods of time $(0.5$ to $4 \mathrm{~h})$. In the organ culture system a moderate latency $(8 \mathrm{~h})$ of the steroidogenic effect of cyclic AMP was noted (Nimrod ef al., in press ; Funkenstein et al., in press). This lag period is compatible with a requirement for de novo protein synthesis : the capability of cyclic AMP to induce protein synthesis is amply documented (Wicks, 1974 ; Di Marco and Oliver, 1978).

In the maturing follicle, the appearance of the $\mathrm{LH}$ receptor on granulosa cells can be induced in vivo (Zeleznik et al., 1974) and in vitro (Nimrod ef al., 1977) by the combined action of FSH and œstrogen. This type of heterologous receptor induction may account for the observed synergistic action of FSH and $\mathrm{LH}$ on progesterone synthesis. However, while FSH was able to augment the response to $\mathrm{LH}$ once the ovaries had attained LH-sensitivity, it was unable to induce a precocious responsiveness to $\mathrm{LH}$ in spite of the presence of FSH-binding sites (vide infra).

The stimulatory action of LH on progesterone secretion was also markedly enhanced by testosterone, while on its own the androgen was ineffective. Although basal œstradiol accumulation by the cultured ovaries was barely detectable and did not increase spontaneously with duration of culture (2-10 days) or in response to either FSH or LH alone, testosterone caused an increase in œstradiol production, suggesting the presence of basal aromatase activity in the early postnatal ovary. It could thus be argued that the enhanced steroidogenic response to $\mathrm{LH}$ by the infantile rat ovary in the presence of testosterone is the result of the conversion of the androgen to œstrogens. Indeed, the onset of responsiveness to exogenous gonadotrophin has been related to the capability of the rat ovary to secrete cestrogens (Reiter et al., 1972 ; Goldenberg, et al., 1973). Cogent evidence for this role of œstrogen has been provided by Kolena (1976b) who showed that administration of depot cstrogen to female rats during the early posinatal period made the ovaries precociously responsive to $\mathrm{LH}$ in terms of cyclic AMP production on Day 6 of life. Oestradiol has a mitogenic action on granulosa cells (Williams, 1945) and a synergistic action on the induction of the granulosa cell LH-receptor (Zeleznik et al., 1974). Whether testosterone increases $\mathrm{LH}$-stimulable ovarian progesterone formation acting on its own or serving as substrate for an active aromatase system is still an open question. Some observations support the former hypothesis. Testosterone has been shown to act synergistically with FSH and with cyclic AMP in stimulating progesterone formation by cultured rat granulosa cells and this effect could not be mimicked by either œstrone or œstradiol (Nimrod and Lindner, 1976).

Continued treatment with FSH and testosterone resulted in an immediate rise in œstrogen formation, indicating that (i) the 4-day old ovaries possess FSH receptors; (ii) FSH induced or activated the aromatase system ; and (iii) œstrogen production at this age is also limited by the availability of aromatizable substrate. The latter conclusion is consistent with the observation that $\mathrm{LH}$ also acted synergistically with FSH in stimulating œstrogen production, since $\mathrm{LH}$ is beleved to induce androgen synthesis by thecal and/or interstitial cells. The LH-FSH synergism was only fully developed 
after $96 \mathrm{~h}$, in agreement with our findings that the neonatal ovary is not responsive to $\mathrm{LH}$ before this time. These observations contrast with those of Levina ef al. (1975) who reported that œstrogen secretion commenced spontaneously in cultured fœial and newborn rat ovary once folliculogenesis was fully established and that the level of œstrogen secretion was unaffected by addition of gonadotrophin to the medium over a 2-3 week culture period.

The newborn rat ovary responds briskly to $P G E_{2}$ in terms of cyclic AMP production even before birth (łable 1 ; Lamprecht et al., 1973 ; Kolena, 1976a). This finding could imply that (i) the ovarian receptor-adenylate cyclase system responsive to $\mathrm{PGE}_{2}$ appears earlier during development than the LH-sensitive system ; (ii) two or more distinct ovarian cell types, differentiating asynchronously, are responsible for the response to the two agonists.

It is concluded that the ability of the neonatal ovary to respond to $\mathrm{LH}$ by the eighth day post partum is acquired by an autonomous developmental process and is not dependent upon previous esposure to gonadotrophins and steroid hormones. However, once sensitivity to the gonadotrophin is attained, steroidogenesis is controlled by an interplay of gonadotrophins and steroid hormones. In contrast to LH, the ovaries are responsive to $\mathrm{PGE}_{2}$ at birth.

4th Workshop on « Development and maturotion of the reproductive organs and functions " Luynes, France, octobre 1978.

Résumé. Le rôle de LH, FSH, PGE $\mathrm{E}_{2}$, AMP cyclique et de la testostérone dans le développement de la capacité de réponse hormonale de l'ovaire néonatal de rattes a été étudié à l'aide d'incubations de courte durée et des cultures d'organes.

Les ovaires périnataux répondent in vitro à $\mathrm{PGE}_{2}$, mais pas à $\mathrm{LH}$, par une augmentation marquée de production d'AMP cyclique. Les ovaires répondent très faiblement à $\mathrm{LH}$ au cours de la première semaine post-partum. Pendant la seconde semaine, la réponse ovarienne aux deux produits augmente nettement. Un modèle comparable de dynamique de réponse à $\mathrm{LH}, \mathrm{FSH}, \mathrm{PGE}_{2}$ ou à de l'AMP cyclique exogène par l'ovaire de jeune ratte est observé lorsque la stimulation hormonale de la décharge d'œstradiol-17 $\beta$ est appréciée à l'issue d'une incubation de $4 \mathrm{~h}$.

Les ovaires de rattes de 4 jours cultivés 2-12 jours dans un milieu sans hormones produisent de petites quantités de stéroïdes qui vont en décroissant. L'addition de LH n'altère pas la production de progestérone pendant les 4 premiers jours de culture, mais la stimule

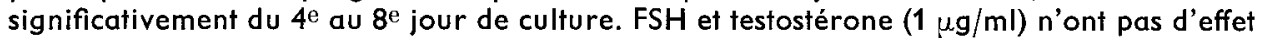
propre, mais lorsque FSH ou la testostérone sont ajoutées à $\mathrm{LH}$, la production de progestérone est fortement augmentée du $4^{\mathrm{e}}$ au $10 \mathrm{e}$ jour de culture. L'acquisition de la réponse à LH ne dépend pas d'une exposition préalable à l'hormone, puisqu'une réponse complète, mesurée par la production de progestérone, est obtenue avec des ovaires après 4 à 8 jours de culture sans addition de $\mathrm{LH}$.

La production d'œstradiol-17 $\beta$ est légèrement augmentée par $\mathrm{LH}$ du $4 \mathrm{e}$ au $10 \mathrm{e}$ jour de culture. FSH n'a pas d'effet propre, mais augmente l'effet de LH. L'addition de testostérone en elle-même stimule significativement la production d'œstradiol, même au cours des deux premiers jours. Cet effet de la testostérone exogène est très augmenté par FSH.

Il est conclu que la capacité de l'ovaire néonatal de répondre à $\mathrm{LH}$ vers le 8 e jour post-partum est acquise par un processus de développement autonome et ne dépend pas d'une exposition préalable aux gonadotrophines et aux hormones stéroïdes. Cependant, une fois que la sensibilité à LH est atteinte, la stérö̈dogenèse est contrôlée par une interaction entre les gonadotrophines et les hormones stéroïdes. Par contre, les ovaires sont capables de répondre à $\mathrm{PGE}_{2}$ dès la naissance. 


\section{References}

ANDERSON C. H., SCHWARTZ N. B., NEQUIN L., ELY C. A., 1976. Effects of early treatment with antiserum to ovine follicle stimulating hormone and luteinizing hormone on gonadal development in rat. Fert. Steril., 27, 47-58.

BAKER T. G., NEAL P., 1973. Initiation and control of meiosis and follicular growth in ovaries of the mouse. Ann. Biol. anim. Bioch. Biophys., 13, 137-144.

DE ANGELO A. B., SCHWEPPE J. S., JUNGMANN R. A., HUBER P., EPPENBERGER U., 1975. Ovarian cyclic adenosine monophosphate-dependent protein kinase activity : Ontogeny and effect of gonadotropins. Endocrinology, 97, 1509-1520.

DI MARCO P. N., OLIVER I. T., 1978. Adenosine 3', 5'-cyclic monophosphate and enzyme induction in the perinatal rat. FEBS Lett., 94, 183-185.

DÖHLER K. D., WUTTKE W., 1975. Changes with age in levels of serum gonadotropins, prolactin and gonadal steroids in prepubertal male and female rats. Endocrinology, 97, 898-907.

ESHKOL A., LUNENFELD B., PETERS H., 1970. Ovarian development in infant mice. Dependence on gonadotropic hormones, 249-258. In BUTT W. R., CROOKE A. C., RYLE M., Gonadotropins and ovarian development. Livingstone, Edinburgh.

FALCK B., 1953. Occurrence of cholesterol and formation of estrogen in the infantile rat ovary. Acta endocrinol., 12, 115-122.

FRIEND J. P., 1977. Persistence of maternally derived ${ }^{3} \mathrm{H}$-estradiol in fetal and neonatal rats. Experentia, 33, 1235-1236.

GOLDENBERG R. L., REITER E. O., ROSS G. T., 1973. Follicle response to exogenous gonadotropins : an estrogen-mediated phenomenon. Fert. Steril., 24, 121-125.

HERTZ R., 1963. Pituitary independence of the prepubertal development of the ovary of rat and rabbit and its pertinence to hypo-ovarianism in women, 120-127. In GRADY H. G., SMITH D. E., The ovary. Williams and Wilkins, Baltimore.

HUNZICKER-DUNN M., BIRNBAUMER L., 1976. Adenyl cyclase activities in ovarian tissues. III. Regulation of responsiveness to LH, FSH and $\mathrm{PGE}_{1}$ in the prepubertal, cycling, pregnant and pseudopregnant rat. Endocrinology, 99, 188-210.

KOCH Y., ZOR U., POMERANTZ S., CHOBSIENG P., LINDNER H. R., 1973. Intrinsic stimulatory action of follicle-stimulating hormone on ovarian adenylate cyclase. J. Endocr., 58, 677-678.

KOLENA J., 1976o. Ontogenic development of the responsiveness in CAMP synthesis to LH and PGE and gonadotropin receptors in rat ovary. Biol. Neon., 29, 96-103.

KOLENA J., 1976b. Reversal of the unresponsiveness of neonatal rat ovary to LH in CAMP synthesis by estrogen. Horm. Res., 7, 152-157.

KRAIEM Z., ESHKOL A., LUNENFELD B., AHREN K., 1976. Ovarian biochemical competence following gonadotrophic deprivation from birth. Acta endocrinol., 82, 388-395.

KRAIEM Z., HEUMAN S., LUNENFELD B., 1979. Ovarian estrogen biosynthesis following gonadotrophic deprivation from birth. Israel J. Med. Sci. (in press).

LAMPRECHT S. A., ZOR U., TSAFRIRI A., LINDNER H. R., 1973. Action of prostaglandin $E_{2}$ and of luteinizing hormone on ovarian adenylate cyclase, protein kinase and ornithine decarboxylase activity during postnatal development and maturity in the rat. J. Endocr., 57, 217-233.

LAMPRECHT S. A., KOHEN F., AUSHER J., ZOR U., LINDNER H. R., 1976. Hormonal stimulation of cestradiol $17 \beta$ release from the rat ovary during early postnatal development. J. Endocr., 68, 343-344.

LEVINA S. E., GYEVAI A., HORVATH E., 1975. Responsiveness of the ovary to gonadotropins in pre- and perinatal life : œstrogen secretion in tissue and organ cultures. J. Endocr., 65, 219-233.

MEIJS-ROELOFS H. M. A., UILENBROEK J. Th. J., DE JONG F. H., WELSCHEN R., 1973. Plasma estradiol-17 $\beta$ and its relationship to serum follicle-stimulating hormone in immature female rats. J. Endocr., 59, 295-304.

MEIJS-ROELOFS H. M. A., DE GREEF W. J., UILENBROEK J. Th. J., 1975. Plasma progesterone and its relationship to serum gonadotropins in immature female rats. J. Endocr., 64, 329-336.

NIMROD A., LINDNER H. R., 1976. A synergistic effect of androgen on the stimulation of progesterone secretion by FSH in cultured rat granulosa cells. Mol. cell. Endocrinol., 5, 315-320. 
NIMROD A., TSAFRIRI A., LINDNER H. R., 1977. In vitro induction of binding sites for hCG in rat granulosa cells by FSH. Nature, 267, 632-633.

PAESI F. J. A., 1949. The influence of hypophysectomy and of subsequent treatment with chorionic gonadotropin on follicles of different size in the ovary of the rat. Acta endocrinol., 64, 89-104.

PERKINS J. P., 1973. Adenyl cyclase, 1-64. In GREENGARD P., ROBISON G. A., Advances in cyclic nucleotide research, Vol. 3, Raven Press, New York.

PETERS H., BYSKOV A. G., LINTERN-MOORE S., FABER M., ANDERSEN M., 1973. The effect of gonadotropin on follicle growth initiation in the neonatal mouse ovary. J. Reprod. Fert., 35, 139-141.

PRESL J., POSPISIL J., FIGAROVL V., WAGNER V., 1972. Developmental changes in uptake of radioactivity by the ovaries, pituitary and uterus after ${ }^{125}$ |-labelled human chorionic gonadotropin administration in rats. J. Endocr., 52, 585-586.

PRICE O., ORTIZ E., 1944. The relation of age to reactivity in the reproductive system of the rat. Endocrinology, 34, 215-239.

PURANDARE T. V., MUNSHI S. R., RAO S. S., 1976. Effects of antisera to gonadotropins on follicular development and fertility of mice. Biol. Reprod., 15, 311-320.

QUATTROPANI S. L., WEISZ J., 1973. Conversion of progesterone to estrone and estradiol in vitro by the ovary of the infantile rat in relation to the development of its interstitial tissue. Endocrinology, 53, 1269-1276.

REITER O. D., GOLDENBERG R. L., VAITUKAITIS J. C., ROSS G. T., 1972. A role for endogenous estrogen in normal ovarian development in the neonatal rat. Endocrinology, 91, 1537-1539.

ROSEN O. M., ROSEN S. M., 1968. The effect of catecholamines on the adenyl cyclase of frog and tadpole erythrocytes. Biochem. Biophys. Res. Commun., 31, 82-91.

SCHMIDT M. J., PALMER E. C., DETTBARN W.-D., ROBISON G. A., 1970. Cyclic AMP and adenyl cyclase in the developing rat brain. Develop. Psychobiol., 3, 53-67.

SCHUCHNER E. B., MONASTIRSKY R. A., 1973. Neutralization of endogenous LH by antibodies in prepubertal female rats. Fert. Steril., 24, 107-119.

SCHWARTZ N. B., 1974. The role of FSH and LH and of their antibodies on follicle growth and on ovulation. Biol. Reprod., 10, 236-272.

SCHWARTZ N. B., ANDERSON C. H., NEQUIN L. G., ELY C. A., 1974. Follicular maturation, 367-381. In GRUMBACH M., GRAVES G., MEYER E., Control of the onset of puberty. WileyInterscience.

SIEBERS J. W., SCHMIDTKE J., ENGEL W., 1977a. hCG-intensitivity of the postantal rat ovary is due to the lack of a specific receptor. Experentia, 33, 689-690.

SIEBERS J. W., PETERS F., ZENZES M. R., SCHMIDTKE J., ENGEL W., 1977 b. Binding of human chorionic gonadotrophin to rat ovary during development. J. Endocr., 73, 491-496.

SMEATON T. C., ARCONDOULIS D. E., STEELE P. A., 1975. The synthesis of testosterone and estradiol-17 $\beta$ by the gonads of neonatal rats in vitro. Steroids, 26, 181-193.

WICKS W. D., 1974. Regulation of protein synthesis by cyclic AMP, 335-438. In GREENGARD P., ROBISON A. G. Advances in cyclic nucleotide res., vol. 4, Raven Press, New York.

WILLIAMS P. C., 1945. Studies on the biological action of serum gonadotrophins. II. Ovarian response after hypophysectomy and estrogen treatment. J. Endocr., 4, 131-145.

ZELEZNIK A. J., MIDGLEY A. R. Jr., REICHERT L. E. Jr., 1974. Granulosa cell maturation in the rat : increasing binding of human chorionic gonadotropin following treatment with folliclestimulating hormone in vivo. Endocrinology, 95, 818-825. 